Marquette University

e-Publications@Marquette

English Faculty Research and Publications

English, Department of

$7-1-2010$

Gothic Chapbooks and the Urban Reader

Diane Hoeveler

Marquette University, diane.hoeveler@marquette.edu

Published version. The Wordsworth Circle, Vol. 42, No. 3 (Summer 2010): 155-158. Publisher Link. (C) 2010 Boston University Editorial Institute. Used with permission. 


\section{Gothic Chapbooks and the Urban Reader}

\section{Diane Long Hoeveler} Marquette University

Gothic bluebooks and chapbooks have been the stepchild of gothic scholarship, frequently ignored because of their derivative nature and their lack of artistic sophistication, depth, or significance (Varma; Frank; Watt). Montague Summers claims that they were the reading material of "schoolboys, prentices, servant-girls, by the whole of that vast population which longed to be in the fashion, to steep themselves in the Gothic Romance." They are commonly referred to as "the remainder trade" or "the trade Gothic" (84-5). William St. Clair has claimed that the chapbooks were read by "adults in the country areas, and young people in both the town and the country. It would be a mistake, therefore, to regard the ancient popular print as confined to those whose education fitted them for nothing longer or textually more difficult. Many readers, whether adults or children, lived at the boundary between the reading and the non-reading nations. They were the marginal reading constituency whose numbers fell when prices rose and rose when prices fell" (343-44). Whatever the class of their intended readership, I would assert that gothic bluebooks and eventually the importance of the gothic short tale requires an understanding of the ambivalent agenda of secularization they carried within their slim and flimsy covers.

Scholars claim that the short gothic tale or chapbook grew out of the earlier tradition of cheap broadside (because printed on one side of the paper) ballads or street literature, and certainly one can see in the short eight-page chapbooks the residue of this direct oral to written tradition (James). Gary Kelly observed that this early street literature is characterized by its "emphasis on destiny, chance, fortune and levelling forces such as death, express[ing] the centuries-old experience of common people. . ..with little or no control over the conditions of their lives. ...For these people, life was a lottery" (2002; 11. x). According to Kelly, the fact that the lower-classes were the target audience of these early productions is also obvious from their very heavy use of narrative repetition, their emphasis on incident and adventure, and their episodic and anecdotal structures. The other major difference between lower and middle-class reading materials is the absence in the lower-class works of any extended depictions of subjectivity or emotions in the protagonists (II. $x$; $\mathrm{xv}$ ). One example of this lower-class ideology appears in Isabella Lewis's Terrific Tales (1804), a series of short vignettes that purport to be true, although the contents are fantastical and reveal an interesting mix of residual supernaturalism combined with rationalizing Christian moral exemplum. For instance, one tale concerns an aristocrat, "of very inordinate passions," who is kidnapped by a spirit who arrived on horseback. Obviously a prose revision and redaction of the Germanic ballad "Lenora," the homily at the conclusion remarks on his abduction as "a punishment for his excessive passions" (7). What is most interesting about these tales, besides their repetitive use of specters, devils, ghosts in chains, warnings from Purgatory, and clouds of sulfur, is their persistent assurance that the afterworld and the realm of the transcendent exists. In one tale, a dead man appears to his friend to exclaim, "Michael, Michael! Nothing is more true than what has been said of the other world" (61), and such a message is the major reason for the popularity of these works. The supernatural was not supposed to be explained away, but instead confirmed as real. Although the elite and the intelligentsia might have been willing to accept the stark lessons of materialism and the finality of death, the lower class was not able to do so, and the gothic chapbook reveals in all its convolutions the persistence and continuing power of the supernatural in the social imaginary (Hoeveler).

The earlier "lottery mentality" that was operative in the lower-class chapbooks was eventually replaced during the late 18 th century by what Kelly calls a dominant "investment mentality" evidenced in the emerging middle-class chapbooks. This "investment mentality" was characterized by the Protestant ideologies of self-improvement, self-advancement, modernization, and self-discipline, or "the middle-class discourse of merit" (II; $\mathrm{x}$; xxiii). Increasingly hostile to lowerclass street literature which appeared politically subversive and at the same time spiritually reactionary, the middle class effectively displaced street literature by co-opting it. Hence Hannah More published her Cheap Repository Tracts (1795-98) for the lower classes, actually imitating cheap broadside and ballad chapbooks and suffusing them not with the "lottery" but with the "investment" mentality that she and her cohorts were attempting to promulgate: a disdain for immediate gratification, a focus on the disastrous consequences of moral relativism, and a stress on the accumulation of "solid and useful" knowledge for middle-class life (Mayo 1942). This strategy is identical to the one that John Guillory has identified as "covert pastoralism" (124) and claimed is operating in Wordsworth's Preface to the Lyrical Ballads. Sensing that they are being marginalized by a bourgeois reading public that has begun to exert power in the literary marketplace, Wordsworth and More create a binary of lower class and aristocrat and actually begin to present themselves as aristocrats in peasant dress.

But if there was a middle-class attempt to co-opt the chapbooks, there was also a concerted effort to condemn their popularity altogether. For instance, Coleridge, in his Biographia Literaria (1817) specifically condemned the "devotees of the circulating library" for indulging in

a sort of beggarly day-dreaming during which the mind of the dreamer furnishes for itself nothing but laziness and a little mawkish sensibility; while the whole material and imagery of the doze is supplied $a b$ extra by a sort of mental camera obscura 
manufactured at the printing office, which pro tempore fixes, reflects and transmits the moving phantasms of one man's delirium, so as to people the barrenness of an hundred other brains afflicted with the same trance or suspension of all common sense and all definite purpose. (III; 36; his italics)

There is a certain amount of fear as well as class resentment expressed here about an unregulated (non-elitist) press pandering to what Wordsworth had called the "fickle tastes, and fickle appetites" of the lower-class reading public (Preface to the Lyrical Ballads, 1800).

The gothic chapbook tradition is split, then, between lower and middle-class agendas, both of which were presenting alternative versions of the secularized uncanny to their readers. One group of tales-the middle-class variety-made claims for the powers of reason, rationality, and secularized education, while, ambivalently, it kept alive the vestiges of a belief in a mythic and sacred past of divine beings. As Kelly notes, the representation of subjectivity is much more developed in these works, but in a writer like John Aikin- a Protestant Dissenter and author of "Sir Bertrand: A Fragment" (1773), a short gothic tale that was written to demonstrate the aesthetic principles put forward in his sister Anna Barbauld's essay "On the Pleasure Derived from Objects of Terror" (1773) - this subjectivity is severely "disciplined" so that the new bourgeois citizens are those who control their emotions in even the most perilous situations (xix). The other group of tales, the lower-class variety, persisted in promulgating a "lottery" view of life, with fate, magic, or luck as the ultimate and inscrutable arbiters in all matters and with human beings still presented as "porous selves" or pawns in the hands of tyrannical forces they could not fully understand. For Kelly, the subjectivity that occasionally appears in lower-class chapbooks is

like the simulation of richer fabrics on cheap printed cottons of the period, [it] is a form of symbolic consumption rather than ideological and cultural instruction for the text's readers. It is as if the readers of the street Gothics were aware that there was a certain model of subjectivity prized in middle-class and upper middle-class culture, but that subjectivity in itself was of little interest, or perhaps supposed to be of little use or value, for these readers. (II; xxiii)

Clearly delimited as a genre that flourished between 1770-1820, the gothic chapbook has been discussed in accusatory tones by critics who blamed it for the eventual decline of the canonical gothic novel. As there are at least one thousand gothic chapbooks currently extant in Britain alone (Potter; Koch; Roy), it is virtually impossible to provide anything other than a snapshot or freeze-frame portrait of the genre. Certainly by the time Edgar Allan Poe was writing his short tales of terror (e.g., "The Tell-Tale Heart" in 1843), he had mastered the formulae necessary to produce a taut and macabre study in gothic psychology and action. Any claim that the gothic tale was moribund by this date is patently false given the artistry that Poe brought to the genre, not to mention that developed by Maupassant in France or Hoffmann in Germany (Mayo 1950) Between Sarah Wilkinson's chapbook "The Subterranean Passage: or Gothic Cell" (1803) and Poe, however, there is a considerable artistic gulf, and it is my intention to try to explain how that gap was bridged through an examination of the evolution and eventual refinement of the subjectivities presented in the gothic tale.

One cannot discuss the gothic chapbook phenomenon without also briefly addressing the development of the circulating library as a "front" so to speak for its own publishing house, William Lane's Minerva Press being the most famous example. Lane's Circulating Library opened in 1770 in London and had ten thousand items in circulation by 1794 (Birkhead). By 1775, circulating libraries were widespread and viewed with more than a little class suspicion. For example, Sir Anthony Absolute in Richard Sheridan's comedy The Rivals says to Mrs. Malaprop: "Madam, a circulating library in a town is as an evergreen tree of diabolical knowledge! It blossoms through the year!-And depend on it, Mrs. Malaprop, that they who are so fond of handling the leaves will long for the fruit at last" (I; 2). This interesting metaphor suggests that the chapbooks may be the "leaves," but the "fruit" is something much more valuable: the possession of culture, class, and cultivation that cheap access to literacy provides.

[While the upper classes viewed circulating libraries with suspicion for the easy access they provided to a modicum of culture, they were viewed by the middle class as important moral guardians to the working class. In the how-to pamphlet The Use of Circulating Libraries Considered (1797), circulating libraries were specifically encouraged to avoid stocking too many chapbooks and pamphlets, but to have $79 \%$ of their stock in fiction. However, library proprietors were also urged to consider the following advice: "Reading and instruction should be universal-the humbler walks of life require much culture; for this purpose I would recommend to their perusal, books of authenticity, in preference to those of entertainment only." From this advice one can infer that the preferable form of fiction was the morally didactic ("the novel") rather than the "romance" (or gothic). The upper class saw the very existence of these libraries, however, as playing a disruptive role in the distribution of cultural materials that encouraged the working classes in their misguided and even dangerous social aspirations; (Blakey 111-24; Jacobs 157-235; Potter 114-36; and Hume). Richter, for instance, connects the rise of circulating libraries with the increase in more naïve readers $(1988 ; 126)$, while Punter argues the opposite, claiming that the "confidence trick" that gothic authors play on their readers (making them believe in phantoms only to sneer at the belief) actually "demands a type of discrimination largely unnecessary in the reading of earlier realist fiction" (1996; 96). 
As literacy rates increased among the lower classes (Stone), the demand for reading materials for them increased as well. It is difficult to know exactly what proportion of the working class purchased their own chapbooks or opted instead to obtain them through a circulating library as either a subscriber or a day-borrower (the latter option would have been the much more economical route to borrowing). Either way, through the act of reading the chapbooks, the lower classes were participating in the ideological and intellectual struggles of their culture. If they could not afford to attend the opera or theater productions in even the "illegitimate" theaters of London, they could read highly condensed redactions and much simplified abridged versions of Walpole, Reeve, Radcliffe, or Lewis's long novels. Doing so allowed the working classes, they thought, to have the same reading experience as the elite and therefore the same access to and ownership of their luxury items

For example, as children, Percy Shelley, Robert Southey, and Walter Scott read the chapbooks (Potter 37), and there is a certain appeal in the child-like simplicity, the distillation of plot, and the flattening of character. More interesting, however, is the confused spiritual ideology they promulgated for the readers: alternately, they advocated either a bourgeois, moralistic, and "investment" mentality (Taylor's concept of the "buffered self") or a "lottery," lowerclass, and fatalistic attitude toward life (Taylor's notion of the "porous self").

The works of one gothic chapbook author, Sarah Scudgell Wilkinson (1779-1831) illustrate the sometimes confused struggle between these two attitudes. Along with Isaac Crookenden (1777-1820), Wilkinson was one of the most prolific writers of gothic chapbooks, the author of some twenty-nine volumes of fiction and more than 100 short works, at least half of which are gothic. Working at times as a writer (and perhaps editor) for Ann Lemoine's Tell-Tale Magazine, or independently trying to support her mother and (possibly illegitimate) daughter Amelia, Wilkinson scratched along as a "scribbler" and owner of a circulating library until she was forced on more than one occasion to apply for financial assistance to the Royal Literary Fund, a form of welfare for indigent and worthy authors. The ideological ambivalence I have been tracing in the chapbooks appears in miniature in Wilkinson's "The White Pilgrim; or, Castle of Olival." Based on the earlier Pixérécourt drama Le Pelerin Blanc (1802), translated into English in 1817 by Henry R. Bishop as "The Wandering Boys; or The Castle of Olival," Wilkinson's version suggests that she was adapting and publishing gothic chapbooks as late as 1818. As the story begins the reader meets the Count of Castelli, "the truly amiable and liberal" Horatio, living with his beautiful wife Amabel, and their two sons in a castle in Berne, Switzerland (311). Devoted to their sons and the welfare of their tenants and dependents, the young couple has made their domain "a second Eden," unaware that there are serpents lurking in the guise of attendants, namely the Chevalier Roland, Seneschal of the castle, and his assistant Otho, Captain of the Guard. Pregnant again, Amabel has a "fearful dream" the night before her husband is to make a short trip to settle some legal affairs with his friend Count Vassali. When she informs her husband of her forebodings, he responds, "'What Amabel superstitious? This is indeed a novelty, for which I was unprepared" (313). Mocking his wife's primitive "superstitions," Horatio next ignores the warning cries of "screechowls and crows" as he begins his journey with his servant Claude, who warns him that the cries of the birds are "illomens" (313). The consummately rational man, Horatio ignores all of these warnings only to leave his family defenseless to the schemes of Roland.

Upon Horatio's return, Amabel's maid, Theresa, informs him that his wife has fled the castle with a paramour ("a near relation of her own, whom you had forbid the castle") seen lurking around the grounds. Believing that she has eloped with a rival, Horatio resigns himself to caring for his sons until he grows restless for travel and a change of scene. Leaving his sons with a tutor, Horatio sets out for England, where he coincidentally discovers the missing maid Theresa, who tells him that she and her father had been bribed by Roland to stage the disappearance of Amabel during Horatio's absence. Horatio further learns that Amabel has in fact been held captive these past three years in a "subterranean cavity" (326) on the castle grounds, and so he begins to plot his revenge by letting it be known that he has perished in a shipwreck during the channel crossing. The resolution of the story occurs when the reader is informed that Roland is the illegitimate brother of Horatio, the son of the former Count and a woman who was "of obscure birth and illiterate manners" (325). When he learns that Horatio has died at sea, Roland now produces a will that allows him to claim all of Horatio's estates (327). At this very moment, the reading of the suspicious will, a pilgrim, "clad in white, his robes, his hat, and staff were all of that virgin hue," appears asking for refuge "after performing his vow of pilgrimage to the shrine of our Lady of Loretto" (327). The appearance of this man is almost atavistic, antediluvian, suggesting the uncanniness of the Catholic past, its ability to erupt as the not-quite repressed that still figures on the edges of this culture. But the white pilgrim is also a melodramatic figure because he is introduced by Roland as "deaf," reminiscent of the "deaf and dumb" characters who inhabit the melodramatic works of Thomas Holcroft.

Thinking that he can safely discuss his plans in the presence of the white pilgrim, Roland reveals to Otho that he intends to poison the orphan boys and kill their mother: "she had long since become an object of disgust and hatred to her betrayer, for she had nobly resisted every attempt to despoil her of her honor and fidelity" (328). The servant Ruffo enables Amabel to escape her dungeon and she tells an abbreviated tale of abuse and misery that recalls the fate of Agnes, the pregnant and imprisoned nun in Lewis's The Monk: "she was delivered prematurely of a child, who died the same 
night; she was allowed no assistance, and having wept many days over her dear blossom, she buried it with her own hands in one corner of the damp dungeon" (334). Whereas her story recalls a literary source, the intended fates of her sons recall a particularly gothic moment in British history, the murder of the two princes in the Tower of London by Richard III in 1483. In an almost-repetition of that crime, this text instead allows the white pilgrim to save the children in the nick of time by substituting a safe potion for the intended poison. One learns later that all of these actions have been orchestrated by the white pilgrim, the avenging husband and father Horatio in disguise. Vassali brings the King's troops to storm the castle, and at the decisive moment, the white pilgrim strips himself of his robes and appears as "the real Count Olival" (335) to denounce the evil machinations of his illegitimate half-brother.

“The White Pilgrim" positions religious as well as class ideologies front and center. By privileging premonitions and ill-omened birds, the lower class is appealed to, while bourgeois attitudes can be detected in the descent of Roland from an "illiterate" mother. There are also clearly lower-class "lottery" elements in this work, as Horatio, an aristocrat, is frequently saved by the most chance-like occurrences (literally running into Theresa on a street in London). There are also bourgeois attitudes present, however, as Horatio rescues his family through cunning, skill, and what one would almost call omniscience. Originally written as a melodrama in France in 1801 and then recast as a British chapbook by Wilkinson around 1818, the text suggests the revenant power of Catholicism and the persistence of superstitions among lower-class readers. In fact, John Kerr's 1820 dramatic version of the work, titled "The Wandering Boys," continued to be so popular that it was performed in the British repertory and published as late as 1894 .

\section{WORKS CITED}

Anon. The Use of Circulating Libraries Considered. Rpt. The Evergreen Tree of Diabolical Knowledge. Ed. Devendra Varma. Consortium Press, 1972. 195-203; Birkhead, Edith. The Tale of Terror: A Siudy of the Gothic Romance. Constable, 1921. Blakey, Dorothy. Minerva Press 1790-1830. Oxford University Press, 1939; Coleridge, Samuel Taylor. Biographia Literaria. 1817; Rpt. Leavitt, 1834; Frank, Frederick. The First Gothics: A Critical Guide to the English Gothic Novel. Garland, 1987; Gallaway, W. F. “The Conservative Attitude toward Fiction, 1770-1830." PMLA 55 (1940): 10459; Guillory, John. Cultural Capital: The Problem of Literary Canon Formation. University of Chi- cago Press, 1993; Haworth, .H. E. "Romantic Female Writers and the Critics." Texas Studies in Literature and Language 17 (1976): 725-36; Hoeveler, Diane Long. Gothic Riffs: Secularizing the Uncanny in the European Imaginary, 1780-1820. Ohio State UP, 2010; Hume, Robert. "The Economics of Culture in London, 16601740." Huntington Library Quarterly 69 (2006): 487-535; Jacobs, Edward. Accidental Migrations: An Archaeology of Gothic Discourse. Bucknell University Press, 2000; James, Louis. Fiction for the Working Man: 1830-1850. Oxford University Press, 1963; Kelly, Gary. "Fiction and the Working Classes." In The Cambridge Companion to Fiction in the Romantic Period. Eds. Richard Maxwell and Katie Trumpener. Cambridge University Press, 2008. 207-33; - "Introduction." In Varieties of Female Gothic. Vol. 2. Street Gothic: Female Gothic Chapbooks. Ed. Gary Kelly. Pickering \& Chatto, 2002. i-xxv; Koch, Angela. "The Absolute Horror of Horrors' Revised: A Bibliographical Checklist of Early-Nineteenth-Century Gothic Bluebooks." Cardiff Corvey: Reading the Romantic Text 9 (December 2002). http://www.cf.ac.uk/encap/ corvey/articles/cc09_n03; —. "Gothic Bluebooks in the Princely Library of Corvey and Beyond." Cardiff Corvey IX. http://www.cardiff.ac.uk/encap/corvey/articles/cc09_n01.html; Mayo, Robert D. "Gothic Romance in the Magazines." PMLA 65 (1950): 762-89; - "The Gothic, Short Story in the Magazines." Modem Language Review 37 (1942): 448-54; Potter, Franz. The History of Gothic Publishing, 1800-1835: Exhuming the Trade. Palgrave, 2005; Richter, David. "The Reception of the Gothic Novel in the 1790s." In The Idea of the Novel in the Eighteenth Century. Ed. Robert Uphaus. Colleagues Press, 1988. 117-37; Roy, G. Ross. "Some Notes on Scottish Chapbooks." Scottish Literary Journal 1 (1974): 50-60; St Clair, William. The Reading Nation in the Romantic Period. Cambridge University Press, 2004; Stone, Lawrence. "Literacy and Education in England, 1640-1900." Past $\mathcal{E}$ Present 42 (1969): 109-125; Summers, Montague. The Gothic Quest: A History of the Gothic Novel. Fortune, 1938; Taylor, Charles. A Secular Age. Harvard University Press, 2007; Watt, William. Shilling Shockers of the Gothic School: A Study of Chapbook Gothic Romances. Russell \& Russell, 1932;Wilkinson, Sarah. "The White Pilgrim." In Varieties of Female Gothic. Dean and Munday, n.d. Rpt. Ed. Gary Kelly. Pickering and Chatto, 2002. II: 307-36; Wordsworth, William. The Prose. ... Eds. W. J. B. Owen, and Jane W. Smyser. 3 vols. Clarendon, 1974. 
Copyright of Wordsworth Circle is the property of Wordsworth Circle, Dr. Marilyn Gaull and its content may not be copied or emailed to multiple sites or posted to a listserv without the copyright holder's express written permission. However, users may print, download, or email articles for individual use. 